\title{
The model of an agrarian entrepreneurial university
}

\author{
E.A. Korotkova ${ }^{1, *}$, M.A. Karabut ${ }^{2}$, and P.N. Shorokhov ${ }^{1}$ \\ ${ }^{1}$ Ural State Agrarian University, Yekaterinburg, Russia \\ ${ }^{2}$ Ural State Federal University named after the first President of Russia B. N. Yeltsin, Yekaterinburg, \\ Russia
}

\begin{abstract}
This paper considers the implementation of the Strategy for the development of the agrobusiness of the Sverdlovsk region. The conclusion is confirmed concerning insufficient development of the business environment in the agrarian sector. Approaches and methods of transformation of the classical agrarian university into an entrepreneurial one on the example of the Ural State Agrarian University are discussed: knowledge generation, teaching and translation of knowledge into practice; reshaping of the university's internal environment; modification of interactions with the external environment developing the university's innovation environment. The results of the project and their significance are predicted: the creation of a modern system of educational, scientific and design-entrepreneurial environment. New educational products will be developed. A set of indicators and marks of compliance of the agrarian university to the entrepreneurial type will be introduced. The uniqueness of this project has been found. The thing is that the Ural State Agrarian University is not a classical or purely technical university and this expands its ability to enter various areas of the region's life: economic, social and technological. The article concludes that the implementation of the project will meet the needs of the agriculture cluster of the Sverdlovsk region in the development of intellectual entrepreneurship and avoid primitive mechanisms of collection and independent implementation of their agricultural products by residents.
\end{abstract}

\section{Introduction}

In the agrarian sector of the Sverdlovsk region (hereinafter - SR) is actively developing efficient production technologies. It enables to output high-quality goods and change the organization of production management. However, the business environment is poorly developed. It may result in, firstly, to the introduction of innovations in existing production technologies; secondly - to the development of small and medium business. Achieving the goal of creating a high-production sector in the agroindustrial complex (hereinafter - APC),

\footnotetext{
*Corresponding author: e.korotkova26@yandex.ru
} 
according to the Decree of the President of the Russian Federation as of May 7, 2018, No. 204 is performed under the national projects (programs) in the areas of:

- development of small and medium business and support of entrepreneurial initiative;

- the development of international cooperation and export.

An analysis of the Sverdlovsk Region Agro-Industrial Development Strategy has demonstrated that it is aimed at ensuring the food security of the population and increasing export potential. It is planned to create new food markets as well as to construct the wholesale and logistics centers. The Sverdlovsk region is pretended to be the region, implementing a policy of economic patriotism in terms of consumption of products of its own production. It is also noted that there is insufficient interaction between trade organizations and food and processing industries. We also revealed a low product advertising. $20 \%$ of the rural population is unemployed. In this regard, it is essential to develop small types of economic and agricultural consumer cooperation. It is also vital to create a system of promotion and positioning of the local output.

The involvement of youth to live in rural areas is still an up-to-date issue. The conditions for solving this problem are perspectives, profitability, the opportunity to set up and run the farm.

Thus, the education system in agrarian universities should be changed. It has to be built in accordance with the needs of business.

Despite the widespread use in the academic literature of the concept of "entrepreneurial university", we highlight the lack of description of the model of an agrarian entrepreneurial university.

\section{Materials and methods}

In order to meet the objectives of the national project and the economic development of the Sverdlovsk region, the Ural State Agrarian University proposes to develop and introduce a project to create and implement a model of entrepreneurial agrarian university. It is aimed at the creation and maintenance of the entrepreneurial environment in the agrarian sector of the Sverdlovsk region through the widespread use of innovative educational programs in its activities, including supplementary vocational education programs for the rural population; findings of applied research and the introduction of innovative developments in the agroindustrial complex of the Sverdlovsk region.

The topic itself is problematic, as it involves a transformation affecting the bridging of the gap between the three cultures: humanitarian, natural science and business [3].

Therefore, there is a contradiction between the educational function of the university and the required customer-focusedness. There is also a conflict between the need for the development of fundamental science and the requirement to create full-cycle innovations focusing on the commercialization of knowledge and innovations in the form of the transfer of intellectual property pieces.

According to Clark B. [4], for example, the implementation of the entrepreneurial university model involves the following changes: diversification of funding, strengthening of the management core and transformation of university collegiality. These are universities, which produce an environment of entrepreneurship and innovation. They promote the development of an entrepreneurial culture, and try to build new reciprocal relationships based on the traditional link between universities and enterprises for the transfer of knowledge and technology, while integrating new management and market practices.

Ropke J. [7] believes that the university becomes an entrepreneurial one. The students and teaches become enterpreneurs. Finally, that the cooperation of university with the region is developing on an entrepreneurial curve. 
The following researches: Konstantinov G.N. and Filonovich S.R. [3] consider that the entrepreneurial university is a higher educational institution, which systematically makes efforts in three spheres: the generation of knowledge into the practice via the initiation of the new forms of activity, transformation of internal environment and modernization of interaction with the outside environment.

Koksharov V.A., Korts S.V., Shulgin D.B. [5] believe that the term entrepreneurial university frequently used as a synonym for innovative university. From their point of view, this assertion is right. Entrepreneurship is impossible without innovation for the university. This is particularly true for the entrepreneurial activity of universities, since the main source of their competitiveness is knowledge and development.

The implementation of the Model of the Ural State Agrarian University as an entrepreneurial university and an organization of regional development presupposes the solution of the following tasks:

- Increasing the interaction of the Ural State Agrarian University with the society as a whole and integrating these types of activities into the educational process together with the partners: the Union of Small and Medium Business of the Sverdlovsk region, etc.

- Considering the particularities of the development of the Sverdlovsk region, which includes a separate socio-economic complex of life-support processes, it is essential to reduce the gaps between the existing innovative developments in the Ural State Agrarian University and the needs of the agroindustrial complex of the region.

- To keep changing the management culture of the Ural State Agrarian University, to enhance the corporate culture, to include extended modules on entrepreneurship in the educational programs of economic specialties, and similar simplified modules in all educational programs of the university; to invite partners to implement these programs.

- To boost the employment of teaching staff and students in the university innovative structure.

\section{Results and discussion}

The entrepreneurial agrarian university model consists of four blocks:

1. Knowledge generation, teaching and translation of knowledge into practice. It presupposes the development of author's multidisciplinary educational programs (modules) on entrepreneurship and their introduction into the educational process of all specialties. Launch of distance and additional education with its own resources, content and organization of the transfer of competencies. Moreover, to develop and implement advanced training programs for the rural population in entrepreneurship.

2. Transformation of the internal environment of the agrarian university. Provides the development of the Center for Social Design and Entrepreneurship. It should be integrated with partners of the Union of Small and Medium Business, Opora Russia. To include in the work of the Center various research teams of the university, specialists in the field of marketing, business and production. The Medium Term Development Framework as well as a competitiveness program for the Ural State Agrarian University should be developed and implemented.

3. Modification of interactions with the outside environment. It updates the mainstreaming of the Ural State Agrarian University in the implementation of regional project "Export of agroindustrial goods of Sverdlovsk region" due to an increase in the quantity of the specialists of agro-economic service. It optimizes the cooperation with partners regarding the new branding of the Ural State Agrarian University of the entrepreneurial type.

4. Innovation environment development of the Ural State Agrarian University. To develop a business incubator together with the partners. To develop full-cycle innovations 
aimed at the commercialization of knowledge and design in the form of the transfer of intellectual property pieces.

The general plan for the transformation of the Ural State Agrarian University into an entrepreneurial agrarian university includes two blocks:

$1^{\text {st }}$ block:

- to develop author's multidisciplinary educational programs (modules) on entrepreneurship for all specialties of the Ural State Agrarian University and additional educational programs for the rural population on entrepreneurship;

- to find and organize opportunities to launch distance and additional education with their own academic resources and entrepreneurial content;

- to create a Center for Social Design and Entrepreneurship together with the Union of Small and Medium Business; to integrate into the work of the Center several research teams of the university, specialists in the field of marketing, business and production.

- to join the implementation of the regional project "Export of agricultural products of the Sverdlovsk region" and boost the number of state-funded places for economic specialties of the Ural State Agrarian University for accumulating the number of specialists of the agroeconomic service in the SR;

- to develop a medium-term development program and a program of competitiveness of the Ural State Agrarian University;

- to sign contracts for the development of full-cycle technological innovations (about 10) for the agroindustrial complex of the SR, focusing on commercialization; to complete the design during this stage;

- to create a brand of the Ural State Agrarian University of the entrepreneurial type;

- to perform arrangements together with partners to open a business incubator in the Ural State Agrarian University.

$2^{\text {nd }}$ block:

- to introduce the author's interdisciplinary educational programs (modules) on entrepreneurship into the educational process of all specialties;

- to strengthen the Ural State Agrarian University in the market of educational services of distance and supplementary education with its own resources, content with the transfer of entrepreneurial competencies;

- to include in the work of the Center various academic teams of the university, namely, specialists in the field of marketing, business and production of SR. To carry out at least five joint events (municipal and regional stages of the competition on entrepreneurship in the territory of SR. To organize the work of stand-up studios, to promote the creation of small enterprises in the agroindustrial complex of SR);

- to develop a Medium-term development program and a program of competitiveness of the Ural State Agrarian University;

- to continue implementing the regional project "Export of products of the agroindustrial complex" and to fulfill a high-quality enrollment in agro-economic specialties;

- to introduce together with customers the innovations fulfilled at the project stage in the agroindustrial complex of the SR;

- to conduct interaction with partners, in terms of the distribution of the new branding of the Ural State Agrarian University of the entrepreneurial type.

- to create a business incubator in the Ural State Agrarian University together with the partners.

Therefore, the novelty of the study is the development of a new-entrepreneurial management system of the agrarian university, as well as the connections and content of the components of the model of the entrepreneurial agrarian university: knowledge generation, transformation of the internal environment of the university, changing relations with the outside environment, development of the innovative environment of the university. 
The topic itself is problematic, as it involves a transformation affecting the bridging of the gap between the three cultures: humanitarian, natural science and business [3].

Therefore, there is a contradiction between the educational function of the university and the required customer-focusedness. There is also a conflict between the need for the development of fundamental science and the requirement to create full-cycle innovations focusing on the commercialization of knowledge and innovations in the form of the transfer of intellectual property pieces.

The difference between this project and others is the following:

- Ural State Agrarian University is not a traditional or purely technical university. It widens and simplifies its possibilities to enter various spheres of the region's life: economic, social and technological $[1,2]$. The introduction of the Ural State Agrarian University into the industrial cluster of the SR through the introduction of its innovations enables it to become a network player in the cluster.

- The article concludes that the implementation of the project will meet the needs of the agriculture cluster of the SR in the development of intellectual entrepreneurship and avoid primitive mechanisms of collection and independent implementation of their agricultural products by residents.

\section{Conclusion and results}

The project implementation is expected to allow for 3-5 years completing the formation of a modern system of educational, scientific, design and innovation business environment in the Ural State Agrarian University, which influences the full range of life support processes in the Sverdlovsk region.

The new educational products, technological innovations, business processes, sources of income and investment will be developed; the intellectual capacity of the university will be used to capitalize, and the key consumers will be determined.

A set of indicators and measures of the level of compliance of the activities of the Ural State Agrarian University with the entrepreneurial type will be completed and implemented: quantitative indicators of the structure; the ratio of various sources of budget and extrabudgetary funding; the level of income from innovations.

The relevance of the results:

The further study and work on the establishment of an entrepreneurial agricultural university will lead to qualitative changes: the success of the realization of the innovation strategy, raising the level of the entrepreneurial culture of the university staff $[6,8]$.

The model of an entrepreneurial agricultural university can be suggested as an object of discussion and, probably, as a model of best practice for other agricultural universities in Russia. Management practices in this area, of course, are the subject of further academic discussion. The pathways of decisions and methods in each university may vary, but the universal principles related to the concept of an entrepreneurial agricultural university are undoubtedly the methodological basis for further research in this area.

\section{References}

1. S.V. Golubev, Soc. Sci. All-Rus. Scien. Jour, 4, 11-21 (2010)

2. G. Ishkovich, The triple helix. Universities-enterprises-the state. Innovation in action, 32 (TURUR, Tomsk, 2010)

3. B.R. Clark, Greating entrepreneurial universities, 319 (Pergamon, Oxford, 1998)

4. G.N. Konstantinov, C.R. Filonovich, Quest of Ed, 1 (2007) 
5. V.A. Koksharov, S.V. Korotkov, D.B. Shulgin, Inn, 11 (2012)

6. A.V. Prokhorov, Ped of th Hig Sch, 21(2), 154 (2011)

7. Ropke J, The Enrepreneurial University Innovation, academic knowledge creation and regional development in a globalized economy. http:/etc. online.uni-marburg. de/etc1/010. pdf.

8. Yu. B. Rubin, Higher education in Russia: quality and competitiveness, (Moscow Military-Industrial Academy, Moscow, 2011) 